\title{
Digitalization: A Literature Review and Research Agenda
}

\author{
João Reis ${ }^{1(\bowtie)}$, Marlene Amorim ${ }^{1}$, Nuno Melão ${ }^{2}$, Yuval Cohen ${ }^{3}$, \\ and Mário Rodrigues ${ }^{4}$ \\ ${ }^{1}$ Department of Economics, Management, Industrial Engineering and Tourism, \\ GOVCOPP, Aveiro University, Aveiro, Portugal \\ \{reis.joao, mamorim\}@ua.pt \\ 2 Department of Management and CISED, \\ School of Technology and Management of Viseu, \\ Polytechnic Institute of Viseu, Viseu, Portugal \\ nmelao@estgv.ipv.pt \\ 3 Department of Industrial and Management Engineering, \\ Afeka Tel-Aviv College of Engineering, Tel-Aviv, Israel \\ yuvalc@afeka.ac.il \\ ${ }^{4}$ IEETA and ESTGA, University of Aveiro, Aveiro, Portugal \\ mjfr@ua.pt
}

\begin{abstract}
Given the noticeable and quick progress of digitalization it is well accepted that digital practices are changing business landscapes. However, while this concept is being labelled in the literature it is also often used indistinctively. To avoid misconceptions, we propose to clarify the concept by providing an overview of the existing theory. This research is one of the first attempts to define the "digitalization" term, and to make a distinction between similar ones. The authors have conducted a systematic review of the existing literature, by identifying and synthesizing the existing body of knowledge. While going digital, firms are expecting to enhance their competitive advantage by offering services throughout virtual channels and operationalize its operations management. Furthermore, the literature suggested the development of new digital technologies along with automation and artificial intelligence is enabling a new wave of smart companies, a topic that deserves to be studied in the future.
\end{abstract}

Keywords: Systematic literature review $\cdot$ Automation $\cdot$ Artificial intelligence Operations management

\section{Introduction}

Digitalization has been identified as the most significant technological trend that is changing both, society and business [1, 2]. Nowadays, firms are constantly under pressure to use digital technologies and to adapt their business models to this new reality [3]. However, although going digital evokes many benefits, it also requires investments and associated costs [4]. Given the noticeable progress of digital technologies [5], the question is how digitalization is being employed by practitioners and into what extent this progress is being followed by scholars and academics. Therefore, 
our main goal is to illustrate the current state-of-the-art and to provide a better understanding of the digitalization term. Interestingly, there are several articles in the literature on digital transformation, but few on digitalization. One of the first literature reviews on digital transformation were notably conducted by Henriette et al. [6], and followed similar research, such as Gebayew et al. [7], Reis et al. [8], Vukšić et al. [9] and Vial [10]. It is well-known that digital transformation term was coined by business professionals and later studied by academics. On the other hand, we also know that the large knowledge gap is currently present at the governmental level, which accounts for only $1 \%$ of world research [8]. In response to the changing expectations, governments are currently changing their mode of operation to improve public service delivery, while public administrators themselves are defining digital transformation in their own day-to-day practices [11]. Thus, in that regard, academics such as Mergel et al. [11] are providing empirical-based definitions of digital transformation retrieved from expert interviews, rather than literature reviews. With regard to digitalization, we could find few literature reviews, one focus on the organizational effects of digitalization by Kuusisto [12] and another research by Parida et al. [13], which developed a framework that communicates and sets the direction for future research by linking digitalization, business model innovation, and sustainability in industrial settings.

This article is structured as follows. Section 2 presents the methodological process, discussing how the systematic review was structured. Section 3 describes the analysis and general discussion of the selected articles. Section 4 concludes the paper, by presenting contributions to theory and practice, as well as the guidelines for future research.

\section{Methodology}

In order to achieve the stated objective, a systematic literature review was employed in order to clarify the digitalization concept, to provide an overview of the existing theory and to suggest guidelines for future research. This method is of particular value due to the uncertainty about what the evidence says about this topic [14], being the right tool to study the phenomenon.

On March 5th, 2019, a search was conducted using Elsevier's Scopus citation database of peer-reviewed literature. The initial search criterion was based on the word "digitalization" in the article titles. To improve our review process and to justify why we chose a certain type of articles and not others, we applied several filters to exclude irrelevant papers and save time [15]. The initial search revealed 1,441 documents, which included journal articles in the English language to enable interpretation. The inclusion criteria focused on management and social sciences, given they are the most promising ones of theoretical research, due to the existence of extensive empirical evidence. The final systematic literature review included 121 articles. Table 1 presents an overview of the review process. 
Table 1. Systematic review process.

\begin{tabular}{l|l|c}
\hline Elsevier's Scopus database & Documents \\
\hline \begin{tabular}{l} 
Search term \\
\multirow{2}{*}{ Digitalization" }
\end{tabular} & All fields & 13,194 \\
\cline { 2 - 3 } & Title-Abstract-Keywords & 7,954 \\
\cline { 2 - 3 } & Article title & 1,441 \\
\hline Language & English & 1,018 \\
\hline Source type & Journal & 572 \\
\hline Document type & Article & 121 \\
\hline $\begin{array}{l}\text { Major subject } \\
\text { area }\end{array}$ & $\begin{array}{l}\text { Social sciences; Business, management and accounting; } \\
\text { and Economics, econometrics and finances }\end{array}$ & \\
\hline
\end{tabular}

We analysed the data through the content analysis technique, which is widely used to detail the proportion or percentage of a text dedicated to a determined subject, and that allowed to make evaluative comparisons of materials with established goals [16]. Content analysis can be briefly defined as the systematic, objective, quantitative analysis of message characteristics - it included both human-coded analysis and computer-aided text analysis [17]. Using a computer-assisted qualitative data analysis software NVivo 11 - QSR International [18], we examined the data by generating codes and clustering the text into hierarchized categories and subcategories to identify patters and establish new relations within the literature. After coding the 121 articles in order to coin a consistent definition of "digitalization" we are now presenting the results of the systematic review in the next section.

\section{Findings}

We have noticed that Nordic European countries are investing on the integration of information and communication technologies (ICT) and digitalization processes [1] in new or existing business models (Fig. 1). While, at the same time, these countries are studying its implications to the business landscape [19], several cases are illustrating the current Nordic investment on digitalization, e.g., manufacturing companies are pursuing servitization strategies, which are increasingly relying on developing digitalization capabilities to interact and co-create value to their customers [20].

Drawing on the results of this research, we found that the development of digital technologies exists along with advancements in artificial intelligence (AI) and automation, which are enabling a new wave of service delivery systems [21-23] and manufacturing innovations [24]. On the other hand, digitalization and servitization of manufacturing processes are moving companies to find competitive advantages through innovative digital business models [25]. Moreover, the literature best identifies supplementary technologies that are identified as facilitator and do have a broader effect on digitalization, examples are: the use of mobile devices that are changing consumer practices and organizational behaviours $[19,26]$. 


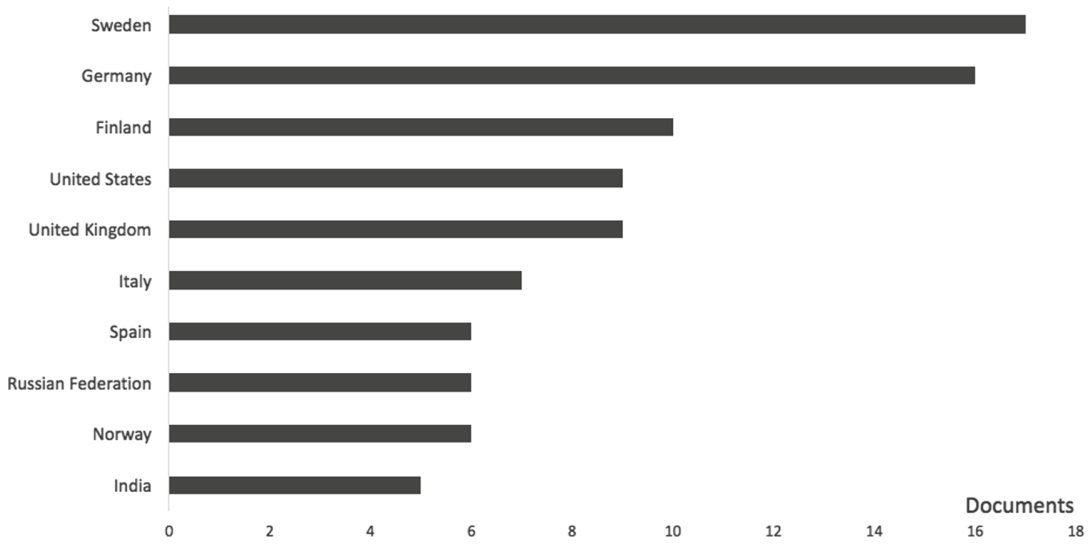

Fig. 1. Documents by country or territory (Top 10).

Interestingly, few articles distinguish between digitalization, digitization, and digitation, which are being sometimes used indistinctly in the literature [8, 27] or, at least, there seems to be quite some confusion regarding the usage of terms [28]. Common themes associated to the aforementioned concepts are digital innovation, digital disruption, digital convergence and digital transformation, which are the abilities of different companies to compete when digitalization alters the dynamics of core technologies and core markets shifts [29]. Srai and Lorentz [30] also argues that much of the literature on digitalization appears to be ambiguous in terms of the exact definition of the term, probably due to the elusiveness of the concept. Only a couple of articles, which are interested in making such distinction, were identified. Notable examples are presented by Clerck [28], where digitalization is presented as "the use of digital technologies and of data in order to create revenue, improve business, replace/transform business processes and create an environment for digital business, whereby digital information is at the core", and Gobble [22] which identifies the term as "digital technologies and probably digitized information, to create the harvest value in new ways". Srai and Lorentz [30] evidences that past contributions mixed e.g. digitalization and digitization, where digitization is the material process of converting analogue streams of information in digital bits [31], thus, digitalization refers to the technology of digitalising information. Ringenson et al. [32] support those definitions and find them useful for highlighting the difference between the technological conditions necessary for digitally related social change (digitization) and the actual change (digitalization). The limited research regarding the usage of terms, evidenced that this is an area to be explored and suggests future research on the topic.

We analysed each definition and then presented the scholar debate around the term, which is summarized in Table 2. 
Table 2. Digitalization definitions.

\begin{tabular}{|c|c|}
\hline Author(s) & Definition(s) \\
\hline $\begin{array}{l}\text { Maxwell and McCain } \\
\text { [33] }\end{array}$ & $\begin{array}{l}\text { Digital technology takes information and breaks it down into its } \\
\text { smallest components. By transforming an analogue signal into } \\
\text { discrete pieces, digitalization makes it possible to manipulate } \\
\text { information, text, graphics, software code, audio, and video in ways } \\
\text { never before thought of, thus its informating, transforming } \\
\text { capabilities }\end{array}$ \\
\hline Hagberg et al. [26] & $\begin{array}{l}\text { Digitalization is one of the most significant on-going } \\
\text { transformation of contemporary society and encompasses many } \\
\text { elements of business and everyday life. Digitalization refers both to } \\
\text { a transformation from "analogue" to "digital" (e.g. a shift from cash } \\
\text { to electronic payments) and to the facilitation of new forms of value } \\
\text { creation (e.g. Accessibility, availability, and transparency) (citing } \\
\text { Amit and Zott [34]) }\end{array}$ \\
\hline Clerck [28] & $\begin{array}{l}\text { Digitalization is defined as the use of digital technologies and of } \\
\text { data in order to create revenue, improve business, replace/transform } \\
\text { business processes and create an environment for digital business, } \\
\text { whereby digital information is at the core }\end{array}$ \\
\hline Lenka et al. [20] & $\begin{array}{l}\text { The industrial management literature defines the digitalization as } \\
\text { the phenomenon of intelligent connected machines that information } \\
\text { and digital technologies power (citing Lerch and Gotsch [35] and } \\
\text { Parida et al. [36]) }\end{array}$ \\
\hline Machekhina [37] & $\begin{array}{l}\text { Digitalization means transformation of all information types (text, } \\
\text { sound, visuals, video and other data from various sources) into the } \\
\text { digital language }\end{array}$ \\
\hline Parviainen et al. [2] & $\begin{array}{l}\text { The action or process of digitizing; the conversion of analogue data } \\
\text { (esp. in later use images, video, and text) into digital form }\end{array}$ \\
\hline $\begin{array}{l}\text { Thorseng and Griot } \\
\text { [38] }\end{array}$ & $\begin{array}{l}\text { The transformation of existing socio-technical structures that were } \\
\text { previously mediated by non-digital artefacts or relationships into } \\
\text { ones that are mediated by digitized artefacts and relationships with } \\
\text { newly embedded digital capabilities (citing Yoo et al. [39]) }\end{array}$ \\
\hline $\begin{array}{l}\text { Valenduc and } \\
\text { Vendramin [40] }\end{array}$ & $\begin{array}{l}\text { The term "digitalisation" is not the irruption of a new revolution, } \\
\text { but the pervasive synergy of digital innovations in the whole } \\
\text { economy and society (citing Perez [41]) }\end{array}$ \\
\hline Crittenden et al. [23] & $\begin{array}{l}\text { Digitalization creates new forms of interaction between companies } \\
\text { and customers through channels (citing Hansen et al. [42]) }\end{array}$ \\
\hline $\begin{array}{l}\text { Devereux and Vella } \\
\text { [43] }\end{array}$ & $\begin{array}{l}\text { Digitalization is the process of spreading of a general purpose } \\
\text { technology. The last similar phenomenon was electrification. } \\
\text { Digitalization of products and services shortens distances between } \\
\text { people and things. It increases mobility. It makes network effects } \\
\text { decisive. It allows the use of specific data to such an extent that it } \\
\text { permits the satisfaction of individual customer needs - be it } \\
\text { consumers or businesses. It opens up ample opportunities for } \\
\text { innovation, investment, and the creation of new businesses and } \\
\text { jobs. Going forward it will be one of the main drivers of sustainable } \\
\text { growth (citing Gaspar et al. [44]) }\end{array}$ \\
\hline
\end{tabular}


Table 2. (continued)

\begin{tabular}{l|l}
\hline Author(s) & Definition(s) \\
\hline Eling and Lehmann & $\begin{array}{l}\text { The integration of the analogue and digital worlds with new } \\
\text { technologies that enhance customer interactions, data availability } \\
\text { and business process }\end{array}$ \\
\hline Gobble [22] & $\begin{array}{l}\text { Digitalization refers to the use of digital technology, and probably } \\
\text { digitized information, to create and harvest value in new ways }\end{array}$ \\
\hline Morley et al. [45] & $\begin{array}{l}\text { Digitalization is the growing application of ICT across the } \\
\text { economy "encompassing a range of digital technologies, concepts } \\
\text { and trends such as artificial intelligence, the "Internet of Things" } \\
\text { (IoT) and the Fourth Industrial Revolution" (citing IEA [46]) }\end{array}$ \\
\hline Ringenson et al. [32] & $\begin{array}{l}\text { Digitalization is about social life's restructuring around digital } \\
\text { communication and media infrastructures (citing [31]) }\end{array}$ \\
\hline Gebre-Mariam and & $\begin{array}{l}\text { Digitalization refers to the development and implementation of ICT } \\
\text { Bystems and concomitant organizational change, it involves the } \\
\text { transformation of socio-technical structures formerly mediated by } \\
\text { non-digital artefacts into ones mediated by digitized artefacts } \\
\text { (citing Yoo et al. [48]) }\end{array}$ \\
\hline Srai and Lorentz [30] & $\begin{array}{l}\text { Digitalization is defined as the way many domains of social life are } \\
\text { restructured around digital communication and media } \\
\text { infrastructures. In simple terms, digitalization may be defined as the } \\
\text { use of digital technologies }\end{array}$ \\
\hline
\end{tabular}

Summarizing the Table 2; the first focused definition was presented by Maxwell and MacCain [33], who considered digitalization as the transformation of analogue signals into digital pieces. The aforementioned description was therefore supported by Hagberg et al. [26], Parviainen et al. [2] and Eling and Lehmann [27]. Whereas Machekhina [37] described digitalization in a broader way, characterizing it as all information types to the digital language. Should be noted that digitalization is the most significant on-going transformation of contemporary society and encompasses several domains of daily life, such as: the social [30, 32], the economic [40], and the organizational domain [27, 47], in order to create and harvest value [22]. In their article, Eling and Lehmann [27] also presented a very similar debate about the concept of digitalization, with the difference that, in the end, they present a middle ground conceptualization, between the broad and the narrow. Likewise, in our view: digitalization is the phenomenon of transforming analogue data into digital language (i.e. digitization), which, in turn, can improve business relationships between customer and companies, bringing added value to the whole economy and society. 
The above definition is somewhat broader and brings back all the domains that were previously identified in the literature - social, economic and organizational. Therefore, it is not surprising to verify that the major subject $\operatorname{areas}^{1}$ (Table 1) are tied together with the minor subject areas (Fig. 2): (1) business, management and accounting (30\%); (2) social sciences (26\%); (3) engineering (10\%), and (4) economics, econometrics and finances $(8 \%)$. During the last two decades, new technological developments such as, the Internet, and smartphones, have profoundly impacted every part of economic, political and social life [49]. The integration of digital devices reorganized the activities of business organization; thus by adopting business process digitalization, companies have started to gain market and operational efficiency [50].

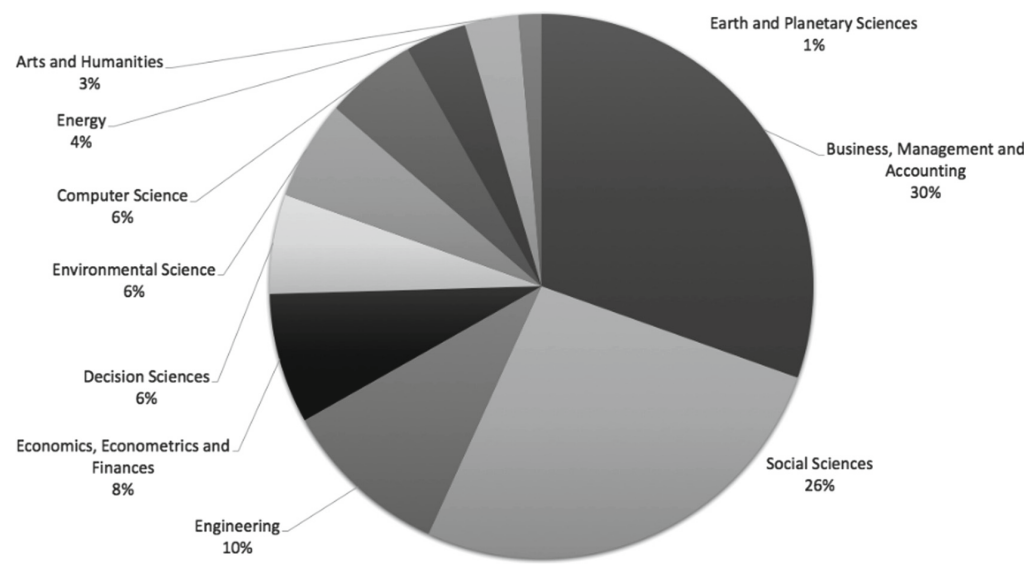

Fig. 2. Documents by subject area.

According to Fig. 2, we could observe that the engineering area has had a great preponderance on the digitalization landscape (10\%), as it is influencing, for example: (1) the improvement of manufacturing processes - industrial engineers [30, 40]; (2) the building of applications - systems engineers [52]; (3) the developments of intelligent machines and artificial intelligence technologies - electrical, mechanical and robotics engineers [27].

We have also explored the journal distribution, which refers to the largest number of publications in the digitalization scope (Fig. 3). We also cross-checked the journal distribution with Scimago $^{2}$ Journal Ranking (SJR indicator), which measures the journal's impact, influence and prestige that is measured from Q1 (best indexed journals) until Q4 (lowest indexed journals).

\footnotetext{
${ }^{1}$ Scopus classified the documents under four broad subject clusters (life sciences, physical sciences, health sciences and social sciences \& humanities), which are further divided into 27 major subject areas and $300+$ minor subject areas [51].

2 https://www.scimagojr.com.
} 
ZWF Zeitschrift fuer Wirtschaftlichen Fabrikbetrieb

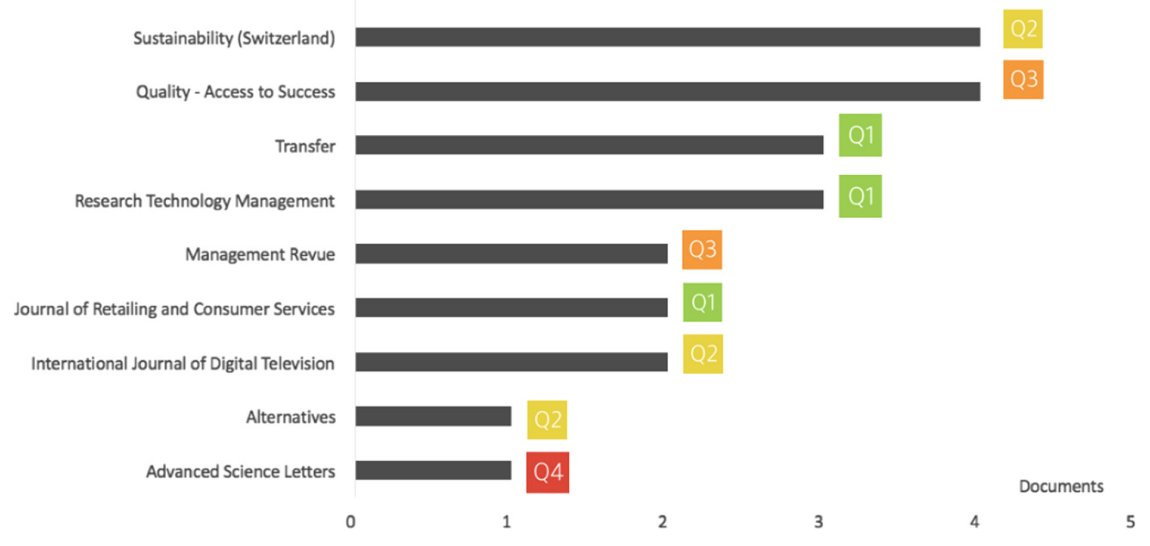

Fig. 3. Documents distribution by journal (Top 10).

The journals with highest percentage of publication were: The German journal of ZWF Zeitschrift für Wirtschaftlichen Fabrikbetrieb, which is mainly addressed to companies' executives and specialists' in production and service engineering domains; the Swiss journal of Sustainability and the Romanian Journal Quality - Access to Success, which are cross-disciplinary, scholarly and open access journals. Although the ones with better quotation were the British Journals Transfer, Research Technology Management, and the Journal of Retailing and Consumer Services. As mentioned above, the highest scientific journal emphasized practice-based research, which is a clear indication that research is largely driven by practitioners; followed by academics, particularly with respect to publications in major journals i.e. between quartiles 1 and 2 .

The bars in Fig. 4 illustrate the dispersion of each research approach. Although the Fig. 4 does not present all the research methodologies and methods, we have considered the generic ones with more incidences, giving just a few examples: mixed methodologies included multimethod research or mixed method research; and empirical research included case studies or focus group.

Figure 4 shows that there is a higher incidence of empirical studies when compared to the conceptual ones, which shows that there is still room to study the phenomenon from a conceptual point of view, so future research should focus more on defining the theoretical foundations of the field. We could also verify that most part of the empirical research were qualitative case studies, which according to Yin [53] have no generalization perspectives, only theoretical, and therefore it would be useful to invest on quantitative research methods to allow generalization. There is also a great lack of mixed studies and therefore it would be more valuable to draw more attention in that regard. Mixed studies allow researchers or a team of researchers to combine elements of qualitative and quantitative research approaches for a broader purpose of breadth and depth of understanding and corroboration [54]. Moreover, there is a level of agreement that mixed studies are superior in comparison with single methods [55, 56], as are less prone to errors or biased conclusions [57]. 


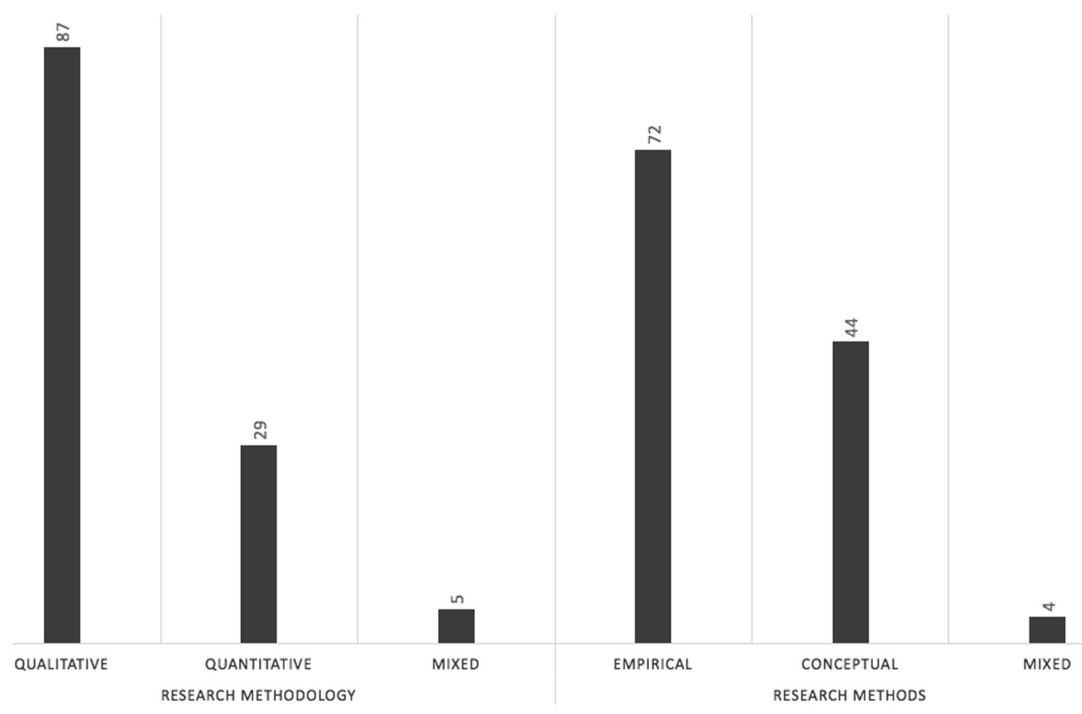

Fig. 4. Major research approaches.

Although the quality of publications increased, i.e. in the first two months of 2019 , approximately $70 \%$ of publications were Q1, the number of publications also increased progressively over the years (Fig. 5). The document distribution increased mainly due the transition of digital technologies from computer science to the service and manufacturing industry, thus the digital transformation is re-shaping the industrial processes: e.g. industry 4.0, industrial artificial intelligence or internet of things.

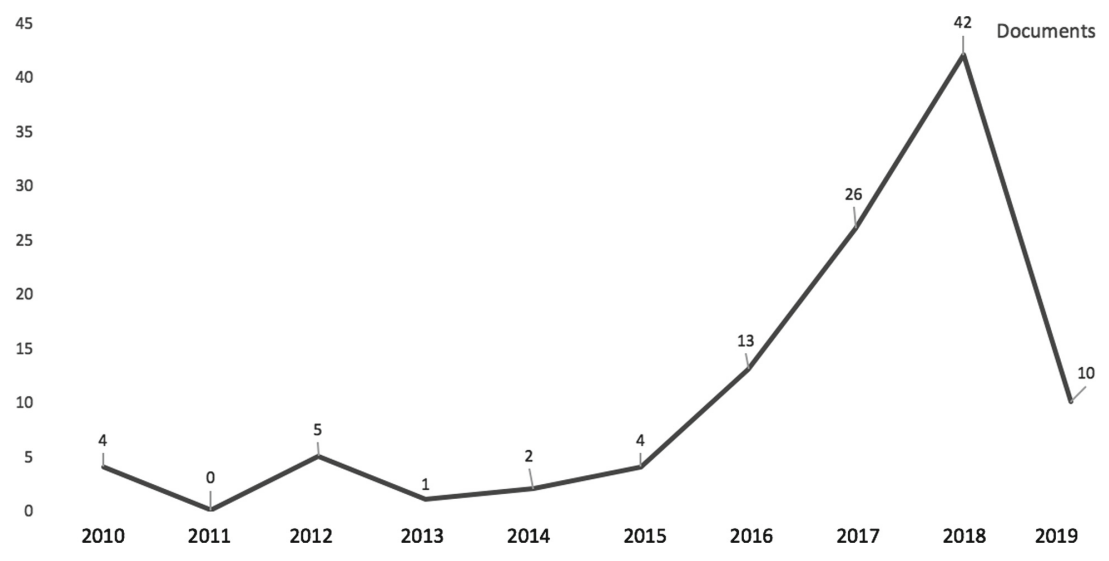

Fig. 5. Documents distribution by year (10 years' period).

The digital era is not only driving innovation into the industry sector, as it seems to being influencing developments in the public sector as well [58]. Moreover, Reis et al. [8] argue the government digitalization is one of the promising themes, with more 
prospects for future development. A perspective that has already been verified in the first two months of 2019, with a slight increase of studies related to public education $[23,59]$ and public health services $[47,51]$ when compared with the same period in 2018. In the next section we present the conclusions, where is included the contributions to theory and practice, as well as the guidelines for future research.

\section{Conclusions}

This study draws on evidences that are paving the way on how new technologies are assisting customers and companies to create value. This article provides cutting-edge results: on the one hand, the developments achieved in the service industry are being made in combination with synergies between digital services and other new technologies, such as AI or IoT; on the manufacturing domain, companies are also pursuing new venues in finding competitive advantages by applying innovative digital practices on their industrial process (e.g. servitization strategies).

Moreover, this study contributes to the digitalization literature, by providing a clear understanding of its foundations in regard to the advancements achieved in the last few years. To strengthen the aforementioned argument, several authors [26, 60] have concluded that additional debate on the digitalization agenda is needed, to further develop a deeper understanding on how digital initiatives are changing existing business models.

This article has some limitations: firstly, the way we choose the search term influences which publications were included in the review, while choosing the term "digitalization" many contributions using synonyms were excluded from this work [61], on the other hand, we must accept that in conducting systematic reviews there is a hierarchy of evidence and that what can be empirically stated about the world is derived from studies in which design is explicit and rigorous [62]; secondly, we only include articles in English, excluding all works in other languages, although we recognize that excluded articles may have different results, we decided to give priority an accurate interpretation of the articles, thus avoiding any kind of misunderstanding; finally, we also know that most systematic reviews use more than one database to be more comprehensive in choosing articles, but for this article we decided to prioritize transparency and easy reproducibility of results.

Future research should aim at a broader understanding of the digitalization phenomenon, therefore our research can be enriched by the analysis of related topics, such as digital disruption, digital convergence or digital divide. Such attempts may focus on presenting a clear definition of the conceptual field, as well as a brief bibliometric analysis of each term. Researchers should also draw on the theoretical foundations of the field of digitalization, identifying existing theories or developing new ones in order to theoretically support novel empirical research. The literature review has also presented other perspectives that have received little attention to date, and which are well highlighted by Martín-Peña et al. [25], such as the challenges and success factors in the transformation from traditional to digital business models [63] and the analysis of strategic implications [64], just to mention some. 
Acknowledgments. The authors gratefully acknowledge the financial support from the Research Unit of Governance, Competitiveness and Public Policies (GOVCOPP) from Aveiro University - Portugal.

\section{References}

1. Leviäkangas, P.: Digitalisation of Finland's transport sector. Technol. Soc. 47(1), 1-15 (2016)

2. Parviainen, P., Tihinen, M., Kääriäinen, J., Teppola, S.: Tackling the digitalization challenge: how to benefit from digitalization in practice. IJISPM 5(1), 63-77 (2017)

3. Kohli, R., Melville, N.: Digital innovation: a review and synthesis. Inform. Syst. J. 29(1), 200-223 (2019)

4. Ahmad, M., Murray, J.: Understanding the connect between digitalisation, sustainability and performance of an organisation. IJBEX 17(1), 83-96 (2019)

5. Bejtkovský, J., Rózsa, Z., Mulyaningsih, D.: A phenomenon of digitalization and erecruitment in business environment. Pol. J. Manag. Stud. 18(1), 58-68 (2018)

6. Henriette, E., Feki, M., Boughzala, I.: The shape of digital transformation: a systematic literature review. In: Proceedings of the Mediterranean Conference on Information Systems, MCIS 2015, pp. 431-443. AISeL Press (2015)

7. Gebayew, C., Hardini, I., Panjaitan, G., Kurniawan, N.: A systematic literature review on digital transformation. In: Proceedings of the International Conference on Information Technology Systems and Innovation, ICITSI 2018, pp. 260-265. IEEE Press (2019)

8. Reis, J., Amorim, M., Melão, N., Matos, P.: Digital transformation: a literature review and guidelines for future research. In: Rocha, Á., Adeli, H., Reis, L.P., Costanzo, S. (eds.) Trends and Advances in Information Systems and Technologies: WorldCIST 2018. AICS, vol. 745, pp. 411-421. Springer, Cham (2018)

9. Vukšić, V., Ivančić, L., Vugec, D.: A preliminary literature review of digital transformation case studies. In: Proceedings of the 20th International Conference on Managing Information Technology, ICMIT 2018, pp. 952-957. World Academy of Science, Engineering and Technology (2018)

10. Vial, G.: Understanding digital transformation: a review and a research agenda. J. Strateg. Inf. Syst. 28(2), 118-144 (2019)

11. Mergel, I., Edelmann, N., Haug, N.: Defining digital transformation: results from expert interviews. Gov. Inform. Q. 34(4), 1-12 (2019)

12. Kuusisto, M.: Organizational effects of digitalization: a literature review. Int. J. Organ. Theor. Behav. 20(03), 341-362 (2017)

13. Parida, V., Sjödin, D., Reim, W.: Reviewing literature on digitalization, business model innovation, and sustainable industry: past achievements and future promises. Sustainability 11(2), 391-1-391-18 (2019)

14. Petticrew, M., Roberts, H.: Systematic Reviews in the Social Sciences: A Practical Guide. Wiley, Hoboken (2008)

15. Reis, J., Amorim, M., Melão, N.: Multichannel service failure and recovery in a $\mathrm{O} 2 \mathrm{O}$ era: a qualitative multi-method research in the banking services industry. Int. J. Prod. Econ. 215(1), 24-33 (2019)

16. Drisko, J., Maschi, T.: Content Analysis: Pocket Guide to Social Work Research Methods. Oxford University Press, Oxford (2015)

17. Neuendorf, K.: The Content Analysis Guidebook. Sage, Thousand Oaks (2016) 
18. Woolf, N., Silver, C.: Qualitative Analysis Using NVivo: The Five-Level QDA® Method. Routledge, Abingdon (2017)

19. Fuentes, C., Bäckström, K., Svingstedt, A.: Smartphones and the reconfiguration of retailscapes: stores, shopping, and digitalization. J. Retail. Consum. Serv. 39(1), 270-278 (2017)

20. Lenka, S., Parida, V., Wincent, J.: Digitalization capabilities as enablers of value co-creation in servitizing firms. Psychol. Market. 34(1), 92-100 (2017)

21. Efimov, V., Lapteva, A.: The future of universities: is digitalization the priority? J. Sib. Fed. Univ. Humanit. Soc. Sci. 11(12), 1925-1946 (2018)

22. Gobble, M.: Digitalization, digitization, and innovation. Res. Technol. Manag. 61(4), 56-59 (2018)

23. Crittenden, W., Biel, I., Lovely III, W.: Embracing digitalization: student learning and new technologies. J. Mark. Educ. 41(1), 5-14 (2019)

24. Sjödin, D., Parida, V., Leksell, M., Petrovic, A.: Smart factory implementation and process innovation: a preliminary maturity model for leveraging digitalization in manufacturing moving to smart factories presents specific challenges that can be addressed through a structured approach focused on people, processes, and technologies. Res. Technol. Manag. 61(5), 22-31 (2018)

25. Martín-Peña, M., Díaz-Garrido, E., Sánchez-López, J.: The digitalization and servitization of manufacturing: a review on digital business models. Strateg. Change 27(2), 91-99 (2018)

26. Hagberg, J., Sundstrom, M., Egels-Zandén, N.: The digitalization of retailing: an exploratory framework. Int. J. Retail Distrib. Manag. 44(7), 694-712 (2016)

27. Eling, M., Lehmann, M.: The impact of digitalization on the insurance value chain and the insurability of risks. Geneva Pap. R. I.-ISS 43(3), 359-396 (2018)

28. Clerck, J.: Digitalization, Digital Transformation: The Differences. i-SCOOP (2017)

29. Åkesson, M., Sørensen, C., Eriksson, C.: Ambidexterity under digitalization: a tale of two decades of new media at a Swedish newspaper. Scand. J. Manag. 34(3), 276-288 (2018)

30. Srai, J., Lorentz, H.: Developing design principles for the digitalisation of purchasing and supply management. J. Purch. Supply Manag. 25(1), 78-98 (2019)

31. Brennen, J., Kreiss, D.: Digitalization. In: Bruhn Jensen, K., Craig, R.T., Pooley, J., Rothenbuhler, E.W. (eds.) The international Encyclopedia of Communication Theory and Philosophy, pp. 1-11. Wiley, Chichester (2016)

32. Ringenson, T., Höjer, M., Kramers, A., Viggedal, A.: Digitalization and environmental aims in municipalities. Sustainability 10(4), 1278-1-1278-16 (2018)

33. Maxwell, L., McCain, T.: Gateway or gatekeeper: the implications of copyright and digitalization on education. Commun. Educ. 46(3), 141-157 (1997)

34. Amit, R., Zott, C.: Value creation in e-business. Strateg. Manag. J. 22(6-7), 493-520 (2001)

35. Lerch, C., Gotsch, M.: Digitalized product-service systems in manufacturing firms: a case study analysis. Res. Technol. Manag. 58(5), 45-52 (2015)

36. Parida, V., Sjodin, D., Lenka, S., Wincent, J.: Developing global service innovation capabilities: how global manufacturers address the challenges of market heterogeneity. Res. Technol. Manag. 58(5), 35-44 (2015)

37. Machekhina, O.: Digital of education as a trend of its modernization and reforming. Revista Espacios 38(40), 26-31 (2017)

38. Thorseng, A., Grisot, M.: Digitalization as institutional work: a case of designing a tool for changing diabetes care. Inform. Technol. People 30(1), 227-243 (2017)

39. Yoo, Y., Lyytinen, K., Thummadi, V., Weiss, A.: Unbounded innovation with digitalization: a case of digital camera. In: Proceedings of the Annual Meeting of the Academy of Management, AOM 2010 (2010) 
40. Valenduc, G., Vendramin, P.: Digitalisation, between disruption and evolution. Transf.: Eur. Rev. Labour Res. 23(2), 121-134 (2017)

41. Perez, C.: From long waves to great surges. Eur. J. Econ. Soc. Syst. 27(1-2), 69-80 (2015)

42. Hansen, D., Shneiderman, B., Smith, M.: Analyzing Social Media Networks with NodeXL: Insights from a Connected World. Morgan Kaufmann-Elsevier, Burlington (2011)

43. Devereux, M., Vella, J.: Debate: implications of digitalization for international corporate tax reform. Intertax 46(6), 550-559 (2018)

44. Gaspar, V., Collin, P., Devereux, M., Jim, H., Varrak, T., Walsh, M., Westberg, B.: Commission expert group on taxation of the digital economy. European Commission (2014)

45. Morley, J., Widdicks, K., Hazas, M.: Digitalisation, energy and data demand: the impact of internet traffic on overall and peak electricity consumption. Energy Res. Soc. Sci. 38(1), 128-137 (2018)

46. IEA: Digitalization \& Energy (2017). http://www.iea.org/digital/

47. Gebre-Mariam, M., Bygstad, B.: Digitalization mechanisms of health management information systems in developing countries. Inf. Organ. 29(1), 1-22 (2019)

48. Yoo, Y., Lyytinen, K., Boland, R., Berente, N.: The next wave of digital innovation: opportunities and challenges: a report on the research workshop 'digital challenges in innovation research'. SSRN Electron. J. (2010). https://doi.org/10.2139/ssrn.1622170

49. Hansen, H., Salskov-Iversen, D.: Remodeling the transformational political realm: partnerships, best-practice schemes, and the digitalization of governance. Alternatives 30 (2), 141-164 (2005)

50. Li, J., Merenda, M., Venkatachalam, A.: Business process digitalization and new product development: an empirical study of small and medium-sized manufacturers. IJEBR 5(1), 4964 (2009)

51. Scopus: Content Coverage Guide, pp. 1-28 (2017). https://www.elsevier.com/_data/assets/ pdf_file/0007/69451/0597-Scopus-Content-Coverage-Guide-US-LETTER-v4-HI-singlesno-ticks.pdf

52. Koch, C., Hansen, G., Jacobsen, K.: Missed opportunities: two case studies of digitalization of FM in hospitals. Facilities 37(7-8), 381-394 (2019)

53. Yin, R.: Case Study Research: Design and Methods. SAGE Publications, Thousand Oaks (2003)

54. Schoonenboom, J., Johnson, R.: How to construct a mixed methods research design. KZfSS 69(2), 107-131 (2017)

55. Given, L. (ed.): The Sage Encyclopedia of Qualitative Research Methods. Sage publications, Thousand Oaks (2008)

56. Seawright, J.: Multi-method Social Science: Combining Qualitative and Quantitative Tools. Cambridge University Press, Cambridge (2016)

57. Choi, T., Cheng, T., Zhao, X.: Multi-methodological research in operations management. Prod. Oper. Manag. 25(3), 379-389 (2016)

58. Kokkinakos, P., Markaki, O., Koussouris, S., Psarras, J.: Digital transformation: is public sector following the enterprise 2.0 paradigm? In: Chugunov, A., Bolgov, R., Kabanov, Y., Kampis, G., Wimmer, M. (eds.) Digital Transformation and Global Society: DTGS 2016. CCIS, vol. 674, pp. 96-105. Springer, Cham (2016)

59. Dormann, M., Hinz, S., Wittmann, E.: Improving school administration through information technology? How digitalisation changes the bureaucratic features of public school administration. Educ. Manag. Adm. Lead. 47(2), 275-290 (2019)

60. Bredmar, K.: Digitalisation of enterprises brings new opportunities to traditional management control. Bus. Syst. Res. J. 8(2), 115-125 (2017)

61. Mustak, M., Jaakkola, E., Halinen, A.: Customer participation and value creation: a systematic review and research implications. J. Serv. Theor. Pract. 23(4), 341-359 (2013) 
62. Bettany-Saltikov, J.: How to Do a Systematic Literature Review in Nursing: A Step-By-Step Guide. McGraw-Hill Education, UK (2012)

63. Kurti, E.: Inherent cognitive dependencies in the transformation of business models from non-digital to digital. In: Persson, A., Stirna, J. (eds.) Advanced Information Systems Engineering Workshops: CAiSE 2015. LNBIP, vol. 215, pp. 131-136. Springer, Cham (2015)

64. Oestreicher-Singer, G., Zalmanson, L.: Content or community? A digital business strategy for content providers in the social age. MIS Q. 37(2), 591-616 (2013) 